\title{
Optimization of the Spent Activated Carbon Regeneration with the Radical Based Advanced Oxidation Processes: Preference of the Most Suitable Process by PROMETHEE Approach
}

Nevim Genç ( $\nabla$ ngenc@kocaeli.edu.tr)

Kocaeli Universitesi https://orcid.org/0000-0002-6185-1090

Elif Durna

Kocaeli Üniversitesi: Kocaeli Universitesi

\section{Esin KACIRA}

Kocaeli Üniversitesi: Kocaeli Universitesi

\section{Research Article}

Keywords: Regeneration, spent activated carbon, advanced oxidation processes, PROMETHEE approach, Response Surface Methodology

Posted Date: May 7th, 2021

DOl: https://doi.org/10.21203/rs.3.rs-382618/v1

License: (c) (1) This work is licensed under a Creative Commons Attribution 4.0 International License. Read Full License

Version of Record: A version of this preprint was published at Environmental Science and Pollution Research on August 21st, 2021. See the published version at https://doi.org/10.1007/s11356-021-15833y. 


\section{Optimization of the spent activated carbon regeneration with the radical based advanced oxidation processes: Preference of the most suitable process by PROMETHEE approach}

\author{
Nevim GENÇ, ${ }^{* 1}$ Elif DURNA ${ }^{2}$ Esin KACIRA $^{3}$ \\ ${ }^{1}$ Department of Environmental Engineering, Faculty of Engineering, Kocaeli University, 41380, Kocaeli, \\ Turkey.ngenc@kocaeli.edu.tr \\ ${ }^{2}$ Department of Environmental Engineering, Faculty of Engineering, Kocaeli University, 41380, Kocaeli, \\ Turkey. \\ ${ }^{3}$ Department of Environmental Engineering, Faculty of Engineering, Kocaeli University, 41380, Kocaeli, \\ Turkey.
}

\section{Abstract}

In this study, regeneration of spent granular activated carbon (GAC) with reactive dye by hydroxyl and sulfate radical based advanced oxidation processes (Microwave (MW) +Persulfate (PS)), (Fe(II)+ PS), and $\left(\mathrm{O}_{3}+\mathrm{H}_{2} \mathrm{O}_{2}\right.$ ) were evaluated. The adsorption of the dye to the GAC surface was characterized by chemisorption and Langmuir isotherm. Regeneration processes have been optimized by the Response Surface Methodology to determine the operating conditions that will provide the highest adsorptive capacity. The optimum conditions of (MW + PS), $(\mathrm{Fe}(\mathrm{II})+\mathrm{PS})$, and $\left(\mathrm{O}_{3}+\mathrm{H}_{2} \mathrm{O}_{2}\right)$ processes were (process PS anion of $45.52 \mathrm{~g} / \mathrm{L}$, pH of 11.4, MW power of 126 $\mathrm{W}$, duration of $14.56 \mathrm{~min}$ ), ( $\mathrm{Fe}$ (II) of $3.58 \mathrm{~g} / \mathrm{L}$, PS anion of $73.5 \mathrm{~g} / \mathrm{L}$, duration of $59.8 \mathrm{~min}$, $\mathrm{pH}$ of 10.9) and $\left(\mathrm{H}_{2} \mathrm{O}_{2}\right.$ of 2.8 mole/L, ozone dose of $98 \%$, duration of $32.8 \mathrm{~min}, \mathrm{pH}$ of 5.3), respectively. For (MW $\left.+\mathrm{PS}\right),(\mathrm{Fe}$ (II) $+\mathrm{PS})$, and $\left(\mathrm{O}_{3}+\mathrm{H}_{2} \mathrm{O}_{2}\right)$ processes, the adsorptive capacity under optimum conditions were found as 4.36, 8.89 and $8.12 \mathrm{mg}$ dye / g GAC respectively. For ( $\mathrm{Fe}$ (II) $+\mathrm{PS}$ ) and $\left(\mathrm{O}_{3}+\mathrm{H}_{2} \mathrm{O}_{2}\right)$ processes these values are approximately equal to the adsorptive capacity of raw GAC (8.01 mg dye / g GAC). The predicted values of the adsorption capacities by the obtained models were in good agreement with the actual experimental results. PROMETHEE approach was used in the preference of the appropriate regeneration process. The adsorptive capacity of regenerated GAC, operating cost of the regeneration process, change in the adsorptive capacity during the regeneration cycle and carbon mass loss criteria were taken into account. The order of preference of regeneration processes was determined as $(\mathrm{Fe}(\mathrm{II})+\mathrm{PS})>(\mathrm{MW}+\mathrm{PS})>\left(\mathrm{O}_{3}+\mathrm{H}_{2} \mathrm{O}_{2}\right)$ considering all criteria.

Keywords: Regeneration, spent activated carbon, advanced oxidation processes, PROMETHEE approach, Response Surface Methodology 


\section{Introduction}

Reactive dyes are highly preferred due to their high photolytic stability, high resistance to microbial shrinkage and superior fastness to the applied fabric (Charnkeitkong and Phoophuangpairoj 2020). The wastewater generated in industries using reactive dyes is intensely colored due to the low fixation degree of these dyes to fabrics, their low adsorption capability and high water solubilities. and low adsorption capabilities (Vakili et al., 2020). Approximately 70\% of reactive dyes have one or more chromophoric azo bridges which are categorized as xenobiotic compounds (Bakht Shokouhi et al. 2020). Different removal techniques have been developed to remove reactive dyes. Among these, adsorption processes have attracted great attention from researchers (Vakili et al. 2020). Adsorption has been found to be one of the most effective treatment processes for textile industry wastewater. Although many different adsorbents have been tried to remove dyes from wastewater, activated carbon is still the most widely used adsorbent for color removal (Lu et al. 2011). Activated carbon is designed for optimum adsorption of large, negatively charged or polar dye molecules. Reactive dye removal is generally moderate (Beulah and Muthukumaran 2020). In industries, when reactors containing granular activated carbon reach their breaking point, granular activated carbon needs to be regenerated or replaced to restore its adsorptive capacity. The regeneration option is normally less expensive than a replacement (Lu et al. 2011). The feasibility of using the adsorption technique depends on the ability to reuse or regenerate the adsorbent material (Santos et al. 2020). Regeneration of spent GAC to be used for several adsorption and regeneration cycles is a more economical and environmentally friendly activated carbon management (McQuillan et al. 2018).

GAC regeneration is highly dependent on the physical properties and pore structure of the carbons (Durán-Jiménez et al. 2019). The main purpose of regeneration is to restore the adsorption capacity of GAC by removing the adsorbed contaminants. This can be done in two different ways. The first case involves regeneration for desorption of compounds adsorbed without GAC reactions and only requires mass transportation from the GAC surface to the other. The second case is related to the possibility of mineralization of the pollutants adsorbed on the GAC (Zanella et al. 2014).

There are many GAC regeneration techniques in the literature (Salvador et al. 2015a; Salvador et al. 2015b; Zanella et al. 2014). Regenerative techniques have disadvantages such as high energy consumption, carbon erosion, pore plugging, and slow regeneration speed and therefore often require secondary processes (McQuillan et al. 2018). 
Compared to other methods, chemical regeneration can be carried out relatively quickly in situ and without carbon erosion or pore structure degradation ( $\mathrm{Lu}$ et al. 2011). Desorption efficiency mainly depends on the hydrophobicity and water solubility of the contaminants. The most commonly used regeneration agents for chemical regeneration can be categorized into two groups as organic solvents and inorganic chemicals. The effectiveness of chemical regeneration depends on the organic / inorganic regeneration agent used and the absorbed contaminants (Larasati et al. 2020). Solubilizing organic regenerating agents are more effective than oxidizing inorganic regenerating agents (Leng and Pinto 1996). In regeneration with inorganic regeneration agents (acidic and basic solutions), the change in the $\mathrm{pH}$ of the solution can affect the surface charge of the adsorbent. Chemical reactions may occur between the adsorbate pollutants and the regenerant solution, which facilitates desorption. The change in the surface of the GAC can positively or negatively affect the adsorption of the pollutant after the regeneration process (Genç et al. 2021; Larasati et al. 2020).

In thermal regeneration, traditional processes consume a lot of time and energy. Due to successive heating and cooling cycles, the pore structure will deteriorate and the adsorption capacity may decrease. Also, attrition, wash-out, and burn-off can occur during thermal regeneration. Microwave regeneration has been recognized as an alternative to traditional thermal regeneration. Delocalized $\pi$ electrons in activated carbon improve high level of microwave absorption and rapid heating. Microwave (MW) regeneration is influenced by the properties of the adsorbent and the the species being adsorbed, the amount and location (Durán-Jiménez et al. 2019). The heating mechanism of MW preserved the carbon matrix (Ania et al. 2005). Microwave contributes to regeneration efficiency and the life cycle of the activated carbon source (Oladejo et al. 2020).

Regeneration of GAC saturated with organic compounds by oxidation may decrease the adsorption capacity of GAC. There can be two situations that cause this. Regeneration can cause chemical and physical changes in the GAC and thus change its adsorption capacity. Or regeneration may result in incomplete decomposition of target pollutants, resulting in the accumulation of intermediate products occupying adsorption sites available for the adsorption of target compounds (Zanella et al. 2014).

AOP-driven regeneration is an innovative technique in place. AOPs can oxidize organic compounds in solution, causing the formation of reactive radicals in aqueous solution (Cabrera-Codony et al. 2015). AOPs are promising low-energy in-situ alternatives for organic compound oxidation. The general purpose of regeneration is to restore the adsorptive capacity by concentrating and immobilizing 
103

pollutants in the adsorbent, converting them into low affinity byproducts. Contaminants on the GAC are converted at or near the surface by reacting with $\mathrm{OH}^{\bullet}$ radicals (Cabrera-Codony et al. 2015). The catalytic production of radicals can be achieved by the GAC surface itself or by oxidizing agent. Although extensive research studies have indicated that processes based on sulphate radicals $\left(\mathrm{SO}_{4}^{-{ }^{-}}\right)$can effectively mineralize pollutants in water, these processes do not appear to perform well in spent GAC regeneration (Liu et al. 2020). A strong oxidizing agent has a high $\mathrm{E}^{\circ}$ value (Zanella et al. 2014). Both acidic $(\mathrm{pH}<3)$ and alkaline homogeneous conditions, acid and hydroxide catalysed persulfate reactions resulted in reduced $\mathrm{SO}_{4}^{-\bullet}$ formation relative to thermal activation (Huling et al. 2011).

Persulfate regeneration has been studied for the regeneration of spent GAC (An et al. 2015; Durna et al. 2020; Huling et al. 2011; Hutson et al. 2012; Jatta et al. 2019; Liang et al. 2009). Persulfate anion $\left(\mathrm{S}_{2} \mathrm{O}_{8}{ }^{2-}\right)$, can be activated in different ways to generate $\mathrm{SO}_{4}^{-{ }^{-}}$, a powerfull non-specific oxidant that exhibits rapid reaction rates and capable of degrading a wide range of contaminants. In this study, two procedures are investigated to generate $\mathrm{SO}_{4}^{-\cdot}$ from $\mathrm{S}_{2} \mathrm{O}_{8}{ }^{2-}$, chemical persulfate activation via $\mathrm{Fe}$ (II) cations, and microwave irradiation. Generation reactions of $\mathrm{SO}_{4}{ }^{-}$are given in eqn (1) and (2).

$\mathrm{S}_{2} \mathrm{O}_{8}^{2-}+\mathrm{MW}$ heat $\rightarrow 2 \mathrm{SO}_{4}^{-\bullet}$

$\mathrm{S}_{2} \mathrm{O}_{8}^{2-}+\mathrm{Fe}(\mathrm{II}) \rightarrow \mathrm{SO}_{4}^{-\bullet}+\mathrm{Fe}(\mathrm{III})+\mathrm{SO}_{4}^{2-}$

GACs containing high phenolic and carboxylic groups have a high polymerization rate (Cabrera-Codony et al. 2015). It has also been proposed that GAC containing oxygen functional groups can act as an activator of the electron transfer mediator. Mechanisms are shown in eqn (3) and (4) (Liang et al. 2009; Salvador et al. 2015b).

$\mathrm{AC}$ surface $-\mathrm{OOH}+\mathrm{S}_{2} \mathrm{O}_{8}^{2-} \rightarrow \mathrm{SO}_{4}^{-\bullet}+\mathrm{AC}$ surface $-\mathrm{OO}^{\bullet}+\mathrm{HSO}_{4}^{-}$

C surface $-\mathrm{OH}+\mathrm{S}_{2} \mathrm{O}_{8}^{2-} \rightarrow \mathrm{SO}_{4}^{-\bullet}+\mathrm{AC}$ surface $-\mathrm{O}^{\bullet}+\mathrm{HSO}_{4}^{-}$

The use of ozone as an oxidant in the regeneration process is of increasing interest. Regeneration processes based on ozonation have been evaluated by researchers (Cabrera-Codony et al. 2015; He et al. 2017; Alvárez’ et al. 2009; Álvarez et al. 2004). In ozone regeneration, ozone is absorbed chemically on the carbon surface and then reacts with adsorbates to become desorbed decomposition products. The degradation of pollutants can take place in two ways. (Salvador et al. 2015b):

The first is direct oxidation with molecular $\mathrm{O}_{3}$, while in the second, $\mathrm{O}_{3}$ can catalytically decompose at the GAC surface and form $\mathrm{OH}^{*}$ and $\mathrm{O}_{2}{ }^{*}$. 
$\mathrm{OH}^{*}$ reacts with GAC, known as the catalytic carboxone process, yielding more reactive oxygen species causing to longer $\mathrm{GAC}$ adsorption and $\mathrm{OH}^{*}$ oxidation and mineralization. In the $\mathrm{O}_{3}$ regeneration, ozone decomposition and $\mathrm{OH}^{\bullet}$ formation can occur heterogeneously on GAC surfaces and homogeneously in aqueous solution (He et al. 2017).

There may be losses of adsorption capacity due to the inability of $\mathrm{O} 3$ to completely remove the adsorbates, partial destruction of the adsorption active areas, and the formation of oxidation products that can block porosity (Salvador et al. 2015b). Due to the low solubility and high decompositions rate of ozone in water, combinations such as peroxane, ozone photolysis and catalytic ozonation have been used to improve the efficiency of the ozonation process (Patel et al. 2019). The chemical composition of the surface of the GAC changes when exposed to oxidative processes such as $\mathrm{O}_{3}, \mathrm{HNO}_{3}$ or $\mathrm{H}_{2} \mathrm{O}_{2}$. Basic areas become acidic due to oxidation, and due to the addition of $\mathrm{O}_{3}$ to the double band of the GAC structure, new acid regions are formed. Besides, micropore volumes and the BET surface area decrease due to low micropore occlusion, the expansion of pores and the formation of surface oxygen groups at the entrance of the pores (Cabrera-Codony et al. 2015). GAC can enhance the $\mathrm{H}_{2} \mathrm{O}_{2}$ decomposition through $\mathrm{OH}^{*}$ formation (Cabrera-Codony et al. 2015).

GAC catalyzed ozonation can enhance the oxidation of organic compounds by initiating the role of GAC in the radical-type chain reactions of ozone decomposition $/ \mathrm{OH}^{*}$ formation. Besides, this technique allows for continuous reactions of oxidizing agents with compounds adsorbed on GAC. GAC has poor catalytic stability due to changes in surface chemistry and filling of active sites with degradation intermediates. In the $\mathrm{O}_{3}$ process, alkaline $\mathrm{pH}$ promotes the formation of $\mathrm{OH}$ (eqn (5-7)) (Bakht Shokouhi et al. 2020).

$\mathrm{O}_{3}+\mathrm{OH}^{-} \rightarrow \mathrm{HO}_{2}^{-}+\mathrm{O}_{2}$

$\mathrm{O}_{3}+\mathrm{HO}_{2}^{-} \rightarrow \mathrm{OH}_{2}^{-}+\mathrm{O}_{3}^{\cdot}$

$\mathrm{O}_{3}^{\cdot}+\mathrm{H}_{2} \mathrm{O}_{2} \rightarrow \mathrm{OH}^{\bullet}+\mathrm{O}_{2}+\mathrm{OH}^{-}$

Advanced oxidation processes are promising technologies as they are very efficient in treatment of toxic and bio-refractory pollutants, low cost and easy to operate. The generated radicals mineralize the contaminants to $\mathrm{CO}_{2}$, water, and inorganic ions (Santos et al. 2020).

The appropriate regeneration technique varies depends on the features of the adsorbate and adsorbent and the interaction between them. Studies on the application of different regeneration techniques to 
spent GAC are limited in the literature. In this study, the performance of different regeneration methods with $\mathrm{SO}^{-}{ }^{-}$and $\mathrm{OH}^{\bullet}$ radical based advanced oxidation processes in spent $\mathrm{GAC}$ regeneration were investigated. In this study, Sunfix red S3B (SR-S3B) reactive dye was used as the model adsorbate. The molecular structure of SR-S3B contains five sulfonic acid functional groups as a side chain and an azo group that gives the dye toxic properties. This azo bond in its structure makes it a significant threat to aquatic flora and fauna as well as human health (Bapat et al. 2021).

In this study, advanced oxidation processes based on $\mathrm{SO}^{-\bullet}$ radicals ((MW + PS), (Fe (II) + PS)) and $\mathrm{OH}^{\bullet}$ radicals $\left(\mathrm{O}_{3}+\mathrm{H}_{2} \mathrm{O}_{2}\right)$ were used as regeneration methods. Operating conditions of regeneration methods were optimized by Response Surface Methodology (RSM) for the maximum adsorptive capacity of regenerated GAC. The most suitable regeneration process was selected by the PROMETHEE method one of the multi criteria decision making methods. In this process, regeneration processes were evaluated according to the adsorptive capacity of the regenerated GAC, the operating cost of the regeneration process, the change in the adsorptive capacity during the regeneration cycle, and the carbon mass loss criteria.

\section{Material and Methods}

\subsection{Materials}

Commercial GAC (Tarkim carbon 204) used in this study was obtained from Tarkim-Carbon Turkey. Reactive anionic azo textile dye Sunfix red S3B (SR-S3B) used as a model pollutant, was obtained from a local textile company. The properties of the GAC and SR-S3B dye used in the study are given in Table 1.

Table 1 Properties of GAC and SR-S3B model dye used in the study

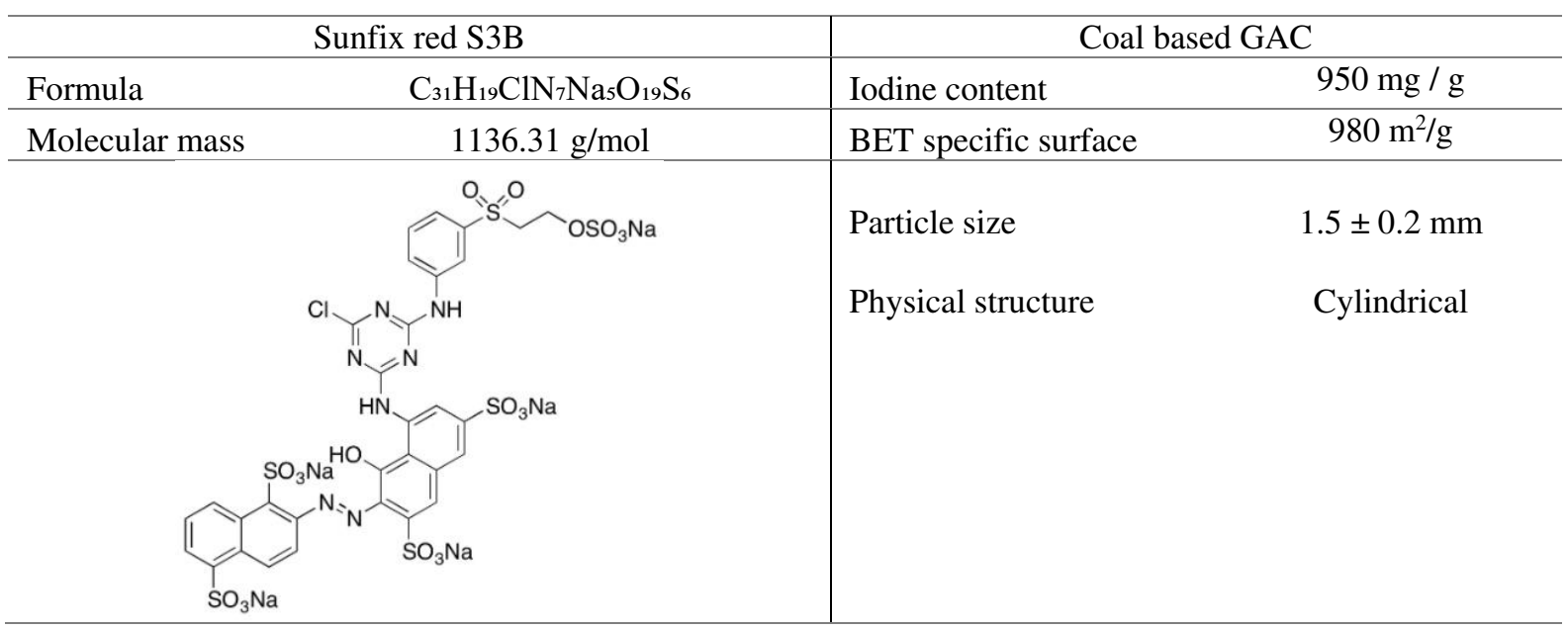



for $\mathrm{pH}$ adjustments and ferrous sulfate $\left(\mathrm{FeSO}_{4} \cdot 7 \mathrm{H}_{2} \mathrm{O}\right)$ used as activator were purchased from Merck. The MW irradiation was used to activate the persulfate anion (PS) in the experiments. The MW furnace with a frequency of $2450 \mathrm{MHz}$ and an irradiation power of up to $700 \mathrm{~W}$ was purchased from CLATRONIC (Model MWG 786). Ozone is produced using the OZ-3G ozone generator. Ozone gas was continuously fed into the GAC-water mixture with a porous diffuser at a flow rate of $6 \mathrm{~L} / \mathrm{min}$. The maximum $(100 \%)$ Ozone content of the ozone generator is $3 \mathrm{~g} / \mathrm{h}$ and the amount of ozone pumped into the reactor has been studied at certain levels as a percentage. The maximum (100\%) ozone content of the ozone generator is $3 \mathrm{~g} / \mathrm{h}$, and it has been used in different percentages according to the experimental design.

192

193

\subsection{Analysis}

Samples obtained from adsorption process were passed through coarse filter to remove GAC particles. All samples were analyzed for SR-S3B concentration. The residual concentration of SR-S3B in the solution was determined by measuring the absorbance at maximum wavelength with a spectrophotometer (Hach Lange DR-6000 UV-VIS Spectrophotometer). The wavelength of the maximum absorbance, $542 \mathrm{~nm}$, was used as the wavelength of the detection. The calibration curve for SR-S3B was established with a $\mathrm{R}^{2}$ of 0.9997 by preparing solutions ranging from $2.5 \mathrm{mg} / \mathrm{L}$ to $30 \mathrm{mg} / \mathrm{L}$. GAC adsorption capacity was calculated according to the following eqn (8).

$q=\left(C_{0}-C_{t}\right) \times V / M$

where $\mathrm{q}$ is adsorption capacity $(\mathrm{mg} / \mathrm{g}), \mathrm{C}_{0}$ and $\mathrm{C}_{\mathrm{t}}(\mathrm{mg} / \mathrm{L})$ are the SR-S3B concentrations at the initial and t, respectively. $\mathrm{V}$ is the volume of the solution (L) and $\mathrm{M}$ is the mass of the adsorbent ( $\mathrm{g}$ ).

The carbon mass loss of adsorbents was determined by the difference between the mass of raw GAC and the mass of regenerated $\mathrm{GAC}$ after evaporating free water at $105^{\circ} \mathrm{C}$.

\subsection{Experimental Methodology}

\subsubsection{Adsorption of SR-S3B}

The adsorption of SR-S3B was analyzed by means of the kinetic and isotherms. Adsorption isotherm was constructed from solution with an initial concentration ranging between $4-30 \mathrm{mg} / \mathrm{L}$. The experiments were made by setting $0.5 \mathrm{~g}$ of raw GAC in contact with $150 \mathrm{ml}$ solution of SR-S3B.

\subsubsection{Regeneration of Spent GAC}


SR-S3B saturation of raw GAC was performed with a concentrated stock SR-S3B solution. The saturation was continued until the GAC could no longer adsorb the SR-S3B. After the GAC was saturated with SR-S3B, the spent GAC was removed from the solution and dried at $100{ }^{\circ} \mathrm{C}$ for 24 hours. The spent GAC was mixed with the regenerating agent/co-solution ( $\left.\mathrm{Fe}(\mathrm{II}) / \mathrm{H}_{2} \mathrm{O}_{2} / \mathrm{S}_{2} \mathrm{O}_{8}{ }^{2-} / \mathrm{O}_{3}\right)$ and exposed to the regeneration. Regenerated adsorbents were used for the next adsorption experiment. The performance of the regeneration process was determined by monitoring the adsorptive capacity of regenerated activated carbon. In this study, used combinations in regeneration of SR-S3B spent GAC were (MW + PS), (Fe (II) + PS) and $\left(\mathrm{O}_{3}+\mathrm{H}_{2} \mathrm{O}_{2}\right)$. Suspensions consist of spent GAC, activator, oxidant, and deionized water was agitated at the experimental conditions. In each regeneration experiment, $0.5 \mathrm{~g}$ of spent GAC was used. After the regeneration process, the regenerated GAC was washed thoroughly with distilled water and the suspended GAC was filtered. After regeneration process, adsorption tests were carried out under SR-S3B concentration of $30 \mathrm{mg} / \mathrm{L}$ at duration of $20 \mathrm{~h}$. Adsorptive capacity of regenerated GAC is defined as response parameter in modelling studies.

\subsubsection{Experimental Design and Optimization by Response Surface Methodology}

225

226

Response Surface Modelling (RSM) is a statistical and mathematical technique useful for improving, developing and optimizing processes in which the response in a process is affected by various variables. The goal is to optimize the response. RSM describes the effect of independent variables on processes, either alone or in combination. In addition to analyzing the effects of independent variables, it creates a mathematical model that can derive beneficial statistical relationships between all parameters in a process based on experimental design (Moyo et al. 2021). In RSM, a series of experimental data is analyzed in which its independent variables vary to investigate the effects on the output response. The Box-Behnken design (BBD) is a symmetrical second order experimental design so that the response surface methodology is rotatable (Rais et al. 2021). BBD requires fewer experimental runs with highly interactive effects between operating parameters providing complete information on optimization (Sahu et al. 2018)

In this study, Box-Behnken experimental design within the scope of response surface methodology (RSM) was used to optimize the processes of GAC regeneration techniques spent on reactive SR-S3B. The four-factor and three-level Box Behnken Design (BBD) was implemented using the Design Expert 11 software. The number of experiments required for optimization determined using eqn 9 (Srikanth et al. 2021). 
$242 N$ is the number of experiments, $C p$ represents the number of replicates for the central points, $k$ represent the

243 number of independent variables.

244 An experimental design of 29 experiments with four independent parameters and five center points was created for all three regeneration processes ((MW + PS), (Fe (II) + PS) and $\left.\left(\mathrm{O}_{3}+\mathrm{H}_{2} \mathrm{O}_{2}\right)\right)$. A quadratic model is preferred according to the regression coefficients. The quadratic model explains the interactions of variables better because it includes singular and interactive effects of the variables. The quadratic model is specified as in the eqn (10).

$y=\beta_{0}+\sum_{i=1}^{k} \beta_{i} x_{i}+\sum_{i=1}^{k} \beta_{i i} x_{i}^{2}+\sum_{i=1}^{k-1} \sum_{i=1}^{k} \beta_{i j} x_{i} x_{j}+\varepsilon$

250

251

252

253

254

255

256

257

258

259

260

261

262

263

264

265

266

267

where $y$ is the response the model predicted, $\beta$ is regression coefficients and $\beta_{0}$ is the intercept. $\beta i, \beta i i$ and $\beta i j$ are regression terms for linear, quadratic and interaction effects. $i$ and $j$ are linear and second order coefficients. $\mathcal{E}$ is the residual error and the number of factors is denoted by k (Barabadi et al. 2019).

The statistical significance of the model was measured with the F-value $(\mathrm{p}<0.05)$ at $95 \%$ confidence interval.

Preliminary studies were taken into consideration in determining the levels of independent parameters for regeneration processes. The factors determined for the (MW + PS) process were PS dosage (25-75 g anion/L), pH (3-12), MW power (126-700 W), and regeneration duration (5-15 min). For the (Fe (II) + PS) process, Fe (II) dosage (0.8- 4 g/L), PS dosage (25-75 g anion/L), pH (3-12) and regeneration duration (10 -60 min) factors were determined. And for the $\left(\mathrm{O}_{3}+\mathrm{H}_{2} \mathrm{O}_{2}\right)$ process, $\mathrm{H}_{2} \mathrm{O}_{2}$ dosage $(0.98-2.98$ $\mathrm{mol} / \mathrm{L})$, Ozone percentage (20-100\%), $\mathrm{pH}(3-13)$ and regeneration duration (30-120 min) factors were determined.

A wide variety of statistics and diagnostics can be obtained from RSM. In this study process parameters were evaluated using an analysis of variance (ANOVA). At the 95\% confidence level, the significance of its parameters was determined using $\mathrm{P}$ values. $\mathrm{P}$ values less than 0.05 indicates that the model terms significant.

\subsubsection{Decision making study}


Multi-criteria decision-making methods are suitable for scoring or ranking a certain number of alternatives when multiple criteria are taken into account. PROMETHEE (Preference Ranking Organization Method for Enrichment Assessment) is a multi-criteria decision making method developed by Brans et al (Brans et al. 1986). After optimization, three regeneration processes (MW + PS), (Fe (II)

$272+$ PS), and $\left(\mathrm{O}_{3}+\mathrm{H}_{2} \mathrm{O}_{2}\right)$ are ranked according to the PROMETHEE approach. Visual PROMETHEE Academic Edition software was used for the PROMETHEE approach. In this study, regeneration processes were evaluated according to the adsorptive capacity of the regenerated GAC, the operating cost of the regeneration process, the change in the adsorptive capacity during the regeneration cycle, and the carbon mass loss criteria.

\section{Result and Discussion}

\subsection{Experimental studies of adsorption}

\subsubsection{Effect of $\mathrm{pH}$ on adsorption capacity}

280

PH can significantly affect the surface properties of GAC. In strongly acidic solutions, the GAC surface is positively charged by protolysis of acid functional groups, which improves the desorption of neutral organic molecules (Leng and Pinto 1996).

In order to observe the effect of solution $\mathrm{pH}$ on adsorption, adsorption was performed by changing the solution $\mathrm{pH}$ values in the range of $1.5-11 \mathrm{pH}$ (Fig. 1). As seen in the $\mathrm{pH}$ profile, SR-S3B removal showed a decrease between solution $\mathrm{pH} \mathrm{4-7}$ and reached a maximum value at $\mathrm{pH} 3.0$ and 11.0. Considering the original $\mathrm{pH}$ (5.5-6) of the SR-S3B solution, since the consumption of chemicals required to adjust the $\mathrm{pH}$ of the solution to 3 was thought to be less than the consumption of chemicals required to raise the $\mathrm{pH}$ to 11 , adsorption experiments were carried out at $\mathrm{pH} 3$.

\footnotetext{
$>$ Fig. 1 Change of the adsorptive capacity versus $\mathrm{pH}$ of reactive dye (SR-S3B) solution<
}

Around $\mathrm{pH} 3$, with the appropriate amount of protons, protonation occurs on the GAC and the charge of the GAC surface changes. Since the initial dissociation acidity constant of sulfonic groups in reactive dyes in aqueous phase is very small $(\mathrm{pKa} \approx 2)$., the sulfonic groups in $\mathrm{SR}-\mathrm{S} 3 \mathrm{~B}(-\mathrm{SO} 3 \mathrm{H})$ are converted to their anionic forms. Therefore, higher dye uptake occurs with enhanced electrostatic interactions between GAC and anionic dye molecules eqn (11-13) (Vakili et al. 2020).

dye $-\mathrm{SO}_{3} \mathrm{H}+\mathrm{H}_{2} \mathrm{O} \rightarrow$ dye $-\mathrm{SO}_{3}^{-}+\mathrm{H}_{3} \mathrm{O}^{+}$ 
299

300

301

302

303

304

305

306

307

308

309

310

311

312

313

314

315

316

317

318

319

320

\subsubsection{Evaluation of adsorption isotherms and kinetics}

Equilibrium data describe how the pollutant interacts with GAC and give a comprehensive understanding of the nature of interaction (Moradi et al. 2013). The Langmuir and Freundlich adsorption isotherms were used to evaluate the transfer of the adsorbate from solution to the adsorbent phase under equilibrium conditions.

In order to investigate the mechanism of adsorption were used kinetic models. To study the mechanism of adsorption of SR-S3B onto GAC and to fit the kinetic data pseudo-first and pseudo-second order kinetic models were used. Kinetics and isotherms parameters were calculated using models listed in Table 2. The most suitable model was chosen according to the linear regression correlation coefficient values $\left(\mathrm{R}^{2}\right) . \mathrm{R}^{2}$ value for the pseudo -first-order model is low; therefore, the adsorption kinetics are well represented by pseudo-second-order kinetic model. In the pseudo-second order model, the rate limiting step is assumed to be chemisorption, involving valence forces through the sharing or exchange of electrons between the adsorbent and the adsorbate (Zhang et al. 2011). A decrease in $\mathrm{k}_{2}$ was obtained with an increase in the initial SR-S3B concentration.

Between the Langmuir and Freundlich isotherms, the Langmuir isotherm fits the experimental data better. The Langmuir isotherm can be represented as the dimensionless separation factor $\mathrm{R}_{\mathrm{L}}$ whose equation is given below (Senthil Kumar 2014).

$R_{L}=\frac{1}{1+K_{L} C_{0}}$

$\mathrm{R}_{\mathrm{L}}$ values were calculated to be between 0.02 and 0.0028 for the initial SR-S3B concentration of 4 to 30 $\mathrm{mg} / \mathrm{L}$. The $\mathrm{R}_{\mathrm{L}}$ value shows the adsorption isotherm is linear $\left(\mathrm{R}_{\mathrm{L}}=1\right)$, favorable $\left(0<\mathrm{R}_{\mathrm{L}}<1\right)$, unfavorable $\left(R_{L}>1\right)$, or irreversible $\left(R_{L}=0\right)$. Since the calculated $R L$ values are between 1 and 0 , this indicates favorable adsorption. The adsorption of SR-S3B dye is energetically encouraged. 
Table 2 Kinetics and isotherm models for SR-S3B adsorption on GAC

\begin{tabular}{|c|c|c|}
\hline Model & Functional form & Constants \\
\hline $\begin{array}{l}\text { Pseudo first } \\
\text { order }\end{array}$ & $\ln \left(q_{e}-q_{t}\right)=\ln q_{e}-k_{1} t$ & $\begin{aligned} \mathrm{R}^{2} & =0.087, \mathrm{Co}=4 \mathrm{mg} / \mathrm{L}, \mathrm{k}_{1}=0.0081 / \mathrm{min}, \mathrm{q}_{\mathrm{e}}=0.15 \mathrm{mg} / \mathrm{g} \\
\mathrm{R}^{2} & =0.978, \mathrm{Co}=8 \mathrm{mg} / \mathrm{L}, \mathrm{k}_{1}=0.2641 / \mathrm{min}, \mathrm{q}_{\mathrm{e}}=0.73 \mathrm{mg} / \mathrm{g} \\
\mathrm{R}^{2} & =0.894, \mathrm{Co}=15 \mathrm{mg} / \mathrm{L}, \mathrm{k}_{1}=0.1191 / \mathrm{min}, \mathrm{q}_{\mathrm{e}}=1.01 \mathrm{mg} / \mathrm{g} \\
\mathrm{R}^{2} & =0.971, \mathrm{Co}=30 \mathrm{mg} / \mathrm{L}, \mathrm{k}_{1}=0.0691 / \mathrm{min}, \mathrm{q}_{\mathrm{e}}=2.62 \mathrm{mg} / \mathrm{g}\end{aligned}$ \\
\hline $\begin{array}{c}\text { Pseudo } \\
\text { second order }\end{array}$ & $\frac{t}{q_{t}}=\frac{1}{k_{2} q_{e}^{2}}+\frac{t}{q_{e}}$ & $\begin{array}{l}\mathrm{R}^{2}=0.955, \mathrm{Co}=4 \mathrm{mg} / \mathrm{L}, \mathrm{k}_{2}=17.27 \mathrm{~L} / \mathrm{mg} \min , \mathrm{q}_{\mathrm{e}}=0.15 \mathrm{mg} / \mathrm{g} \\
\mathrm{R}^{2}=0.983, \mathrm{Co}=8 \mathrm{mg} / \mathrm{L}, \mathrm{k}_{2}=0.297 \mathrm{~L} / \mathrm{mg} \min , \mathrm{q}_{\mathrm{e}}=0.75 \mathrm{mg} / \mathrm{g} \\
\mathrm{R}^{2}=0.988, \mathrm{Co}=15 \mathrm{mg} / \mathrm{L}, \mathrm{k}_{2}=0.083 \mathrm{~L} / \mathrm{mg} \min , \mathrm{q}_{\mathrm{e}}=1.62 \mathrm{mg} / \mathrm{g} \\
\mathrm{R}^{2}=0.986, \mathrm{Co}=30 \mathrm{mg} / \mathrm{L}, \mathrm{k}_{2}=0.029 \mathrm{~L} / \mathrm{mg} \min , \mathrm{q}_{\mathrm{e}}=3.22 \mathrm{mg} / \mathrm{g}\end{array}$ \\
\hline Freundlich & $\ln q_{e}=\ln K_{f}+\frac{1}{n} \ln C_{e}$ & $\mathrm{R}^{2}=0.919, \mathrm{~K}_{\mathrm{f}}=0.618 \mathrm{~L} / \mathrm{g}, \mathrm{n}=1,842$ \\
\hline Langmuir & $\frac{1}{q_{e}}=\frac{1}{q_{m}}+\frac{1}{q_{m} K_{L}}\left(\frac{1}{C_{e}}\right)$ & $\mathrm{R}^{2}=0.951, \mathrm{q}_{\mathrm{m}}=1.198 \mathrm{mg} / \mathrm{g}, \mathrm{K}_{\mathrm{L}}=12.08 \mathrm{~L} / \mathrm{mg}$ \\
\hline
\end{tabular}

$\mathrm{k}_{2}$ is the second order rate constant $(\mathrm{L} / \mathrm{mg} \min ), \mathrm{k}_{1}$ is the first-order rate constant $(1 / \mathrm{min}), \mathrm{q}_{\mathrm{e}}$ is the amount of SR-S3B adsorbed per unit mass of $\mathrm{GAC}(\mathrm{mg} / \mathrm{g}), \mathrm{q}_{\mathrm{m}}(\mathrm{mg} / \mathrm{g})$ and $\mathrm{K}_{\mathrm{L}}(\mathrm{L} / \mathrm{mg})$ are the Langmuir isotherm constants for adsorption capacity and rate of adsorption, respectively. $\mathrm{K}_{\mathrm{f}}(\mathrm{L} / \mathrm{g})$ and $\mathrm{n}$ are Freundlich isotherm constants.

\subsubsection{Optimization of Regeneration Processes}

Advanced oxidation processes based on $\mathrm{SO}_{4}^{-\bullet}$ and $\mathrm{OH}^{\bullet}$ radicals have been evaluated in the regeneration of reactive SR-S3B spent GAC. To distinguish the impact of $\mathrm{H}_{2} \mathrm{O}_{2}, \mathrm{Fe}$ (II) and $\mathrm{MW}$ in $\left(\mathrm{O}_{3}+\mathrm{H}_{2} \mathrm{O}_{2}\right),(\mathrm{Fe}$ (II) + PS) and (MW + PS) regeneration processes, separate experiments were performed with ozonization without $\mathrm{H}_{2} \mathrm{O}_{2}$, PS oxidation without Fe (II) and MW. Persulfate is a weak oxidant, but it can be converted to $\mathrm{SO}_{4}^{-\bullet}$ radical by reacting with functional groups on the GAC surface. MW and Fe (II) activators accelerate this radical formation. When using PS alone in the regeneration of spent activated carbon, the adsorptive capacity obtained increased 2 and 2.6 times, respectively, when used together with Fe (II) and MW. It was determined that the adsorptive capacity obtained when using ozone alone as an oxidizing agent increased 2.7 times with the addition of $\mathrm{H}_{2} \mathrm{O}_{2}$ as the $\mathrm{OH}^{\bullet}$ radical source. These preliminary experiments have shown that the use of oxidants alone cannot sufficiently improve the adsorptive capacity of spent GAC, and higher adsorptive capacities are achieved with the combination of activators and oxidants. Considering these preliminary trials, (MW + PS), (Fe (II) + PS) and $\left(\mathrm{O}_{3}+\mathrm{H}_{2} \mathrm{O}_{2}\right)$ processes and their factors/levels were evaluated for the regeneration of GAC saturated with SR-S3B. In the optimization study, the adsorptive capacity (qe (mg dye / g GAC)) of regenerated GAC was considered as a response parameter. BBD was used for optimization of three regeneration processes. The experimental sets applied for each regeneration process, and the adsorptive capacity $\left(\mathrm{q}_{\mathrm{e}}\right)$ results obtained with the experimental results are given in the supplementary information Table S1, S2, S3.

ANOVA was used to define the relationship between dependent and independent parameters The ANOVA results and model equations obtained for three regeneration processes are given in the Table 3 . A $\mathrm{P}$ value greater than 0.10 indicates that the model terms are not significant, while $\mathrm{P}$ values less than 
0.05 indicate the significance of the model (Singh et al. 2019) According to the $P$ values obtained from the ANOVA, the models of all three regeneration processes were found to be significant $(p<0.05)$. Similarly, for the models of (MW + PS), (Fe (II) + PS) and $\left(\mathrm{O}_{3}+\mathrm{H}_{2} \mathrm{O}_{2}\right)$ processes, the F values obtained as $2.83,3.39$, and 4.57 respectively, emphasize that the models are significant. It has been observed that the individual effects of the parameters affecting the response in the $(\mathrm{MW}+\mathrm{PS})$ process are not important, but the interactive effects of the $\mathrm{BD}, \mathrm{CD}, \mathrm{A}^{2}$ and $\mathrm{D}^{2}$ parameters are important. The parameters affecting the response in the $(\mathrm{Fe}(\mathrm{II})+\mathrm{PS})$ process were $\mathrm{D}, \mathrm{AC}, \mathrm{BC}, \mathrm{BD}$ an $\mathrm{A}^{2}$ and the parameters affecting the response in the $\left(\mathrm{O}_{3}+\mathrm{H}_{2} \mathrm{O}_{2}\right)$ process were $\mathrm{C}, \mathrm{AC}, \mathrm{C}^{2}$ and $\mathrm{D}^{2}$.

Adeq Precision measures the signal-to-noise ratio and an Adeq Precision value of greater than 4 is desired. Adeq precision values obtained by (MW $+\mathrm{PS}),(\mathrm{Fe}(\mathrm{II})+\mathrm{PS})$ and $\left(\mathrm{O}_{3}+\mathrm{H}_{2} \mathrm{O}_{2}\right)$ processes were found to be $6.78,7.72$, and 9.22, respectively, and indicate an adequate signal. The models obtained for all regeneration processes can be used to navigate the design area.

For contour graphs, factors whose interactions were important $(\mathrm{P}<0.05)$ in the ANOVA, were taken into account. In contour graphs, the intersections of the variable on the $\mathrm{x}$ axis and the variable on the $\mathrm{y}$ axis give contour curves. Numerical values on contour curves express $\mathrm{q}_{\mathrm{e}}$ values.

In the (MW + PS) regeneration process (Fig. 2 (a)), an average adsorptive capacity of $4.6 \mathrm{mg} / \mathrm{g}$ GAC is predicted at MW $126 \mathrm{~W}$ and duration of 10 to $15 \mathrm{~min}$. Similarly, an average adsorptive capacity of 4.7 $\mathrm{mg}$ dye / $\mathrm{g}$ GAC is predicted at MW $700 \mathrm{~W}$ and duration of 5 to $9 \mathrm{~min}$. In the process, the lowest value of the adsorptive capacity (1.9 mg dye / g GAC) was predicted at the highest conditions of MW power and duration. In the (Fe (II) + PS) regeneration process (Fig. 2 (b)), an average adsorptive capacity of $6.5 \mathrm{mg} / \mathrm{g} \mathrm{GAC}$ is predicted at $\mathrm{Fe}$ (II) of 4 to $6 \mathrm{~g} / \mathrm{L}$ and duration of 40 to $60 \mathrm{~min}$. The lowest adsorptive capacity value (3.4 mg dye/g GAC) was predicted at the highest Fe (II) concentration and the lowest duration.

In the $\left(\mathrm{O}_{3}+\mathrm{H}_{2} \mathrm{O}_{2}\right)$ regeneration process (Fig. 2 (c)), an average adsorptive capacity of $7 \mathrm{mg} / \mathrm{g}$ GAC is predicted at $\mathrm{H}_{2} \mathrm{O}_{2}$ of 2.5 to $3 \mathrm{~mole} / \mathrm{L}$ and duration of 30 to $40 \mathrm{~min}$. The lowest adsorptive capacity value ( $3.3 \mathrm{mg}$ dye / g GAC) was predicted at $\mathrm{H}_{2} \mathrm{O}_{2}$ of 2.5 to 3 mole/L concentration and duration of 90 to 120 $\min$.

$>$ Fig. 2 Contour graphs of binary interactions of important parameters in regeneration processes (a), (b) and (c) corresponds (MW + PS), $(\mathrm{Fe}$ (II) $+\mathrm{PS})$ and $\left(\mathrm{O}_{3}+\mathrm{H}_{2} \mathrm{O}_{2}\right)$ processes, respectively< 
376 As shown in Fig. 3 for all regeneration processes, the predicted values of the adsorption capacities obtained from the models and the actual experimental results were in good agreement.

>Fig. 3 Predicted versus actual plots of regeneration processes (a), (b) and (c) corresponds (MW + PS), (Fe (II) + PS) and $\left(\mathrm{O}_{3}+\mathrm{H}_{2} \mathrm{O}_{2}\right)$ processes, respectively $<$

Optimum conditions and possible oxidation mechanisms of regeneration processes are given in Fig 4.

382

>Fig. 4 Optimum conditions and possible oxidation mechanisms of regeneration processes <

Optimum conditions obtained for the three regeneration processes are given in supplementary information (Fig. S1-S3). The adsorptive capacities predicted by the obtained models under optimum conditions were 5.40, 7.11 and 7.85 for $(\mathrm{MW}+\mathrm{PS}),(\mathrm{Fe}(\mathrm{II})+\mathrm{PS})$ and $\left(\mathrm{O}_{3}+\mathrm{H}_{2} \mathrm{O}_{2}\right)$ processes, respectively. Validation experiments were carried out under optimum conditions for the three regeneration processes. Adsorptive capacities obtained under optimum conditions were found as 4.36 , 8.89 and 8.12 for $(\mathrm{MW}+\mathrm{PS}),(\mathrm{Fe}(\mathrm{II})+\mathrm{PS})$ and $\left(\mathrm{O}_{3}+\mathrm{H}_{2} \mathrm{O}_{2}\right)$ processes, respectively. Accordingly, the confirmation experiments obtained are in $95 \%$ confidence interval. 
Table 3 The F, P, R², lack of fit, Adeq Precision values of model terms from ANOVA and model equations

\begin{tabular}{|c|c|c|c|}
\hline Source & \multicolumn{2}{|c|}{ (MW+PS) Process } & \multirow{2}{*}{$\begin{array}{c}\text { Model Equation } \\
q_{e}(\mathrm{mg} \text { dye } / \mathrm{g} \text { GAC })=-1.88919+0.097430 \times \mathrm{A}-\end{array}$} \\
\hline & F value & $\mathrm{P}$ value & \\
\hline Model & 2.83 & 0.0305 & $0.063025 \times \mathrm{B}+1.19767 \times \mathrm{C}+0.562717 \times \mathrm{D}-$ \\
\hline A (PS) & 0.12 & 0.7354 & $0.002498 \times(\mathrm{A} \times \mathrm{B})++0.007030 \times(\mathrm{A} \times \mathrm{C})+0.001876 \times$ \\
\hline $\mathrm{B}(\mathrm{pH})$ & 4.07 & 0.0634 & $(\mathrm{~A} \times \mathrm{D})+0.047278 \times(\mathrm{B} \times \mathrm{C})+0.039144 \times(\mathrm{B} \times \mathrm{D})-$ \\
\hline C (MW power) & 0.54 & 0.4740 & $0.252950 \times(C \times D)-0.001143 \times A^{2}-0.013786 \times B^{2}+$ \\
\hline $\mathrm{D}$ (Duration) & 2.45 & 0.1401 & $0.118958 \times \mathrm{C}^{2}-0.025397 \times \mathrm{D}^{2}$ \\
\hline $\mathrm{AB}$ & 0.63 & 0.4392 & $\mathrm{R}^{2}: 0.739$ \\
\hline $\mathrm{AC}$ & 0.25 & 0.6262 & Adeq Precision: 6.780 \\
\hline $\mathrm{AD}$ & 0.44 & 0.5172 & \\
\hline $\mathrm{BC}$ & 0.36 & 0.5562 & \\
\hline $\mathrm{BD}$ & 6.23 & 0.0257 & \\
\hline $\mathrm{CD}$ & 12.84 & 0.0030 & \\
\hline $\mathrm{A}^{2}$ & 6.65 & 0.0219 & \\
\hline $\mathrm{B}^{2}$ & 1.01 & 0.3308 & \\
\hline $\mathrm{C}^{2}$ & 0.18 & 0.6743 & \\
\hline $\mathrm{D}^{2}$ & 5.25 & 0.0380 & \\
\hline Source & \multicolumn{2}{|c|}{ (Fe (II) +PS) Process } & Model Equation \\
\hline & F value & P value & $q_{e}(\mathrm{mg}$ dye $/ \mathrm{g} \mathrm{GAC})=+7.65768+1.34870 \times \mathrm{A}-$ \\
\hline Model & 3.39 & 0.0147 & $0.059705 \times \mathrm{B}-0.089912 \times \mathrm{C}-0.499566 \times \mathrm{D}-$ \\
\hline $\mathrm{A}(\mathrm{Fe}(\mathrm{II}))$ & 1.34 & 0.2661 & $0.009250 \times(\mathrm{A} \times \mathrm{B})+0.019969 \times(\mathrm{A} \times \mathrm{C})-0.021007 \times$ \\
\hline $\mathrm{B}(\mathrm{PS})$ & 0.01 & 0.9072 & $(A \times D)+0.001189 \times(B \times C)+0.004731 \times(B \times D)+$ \\
\hline $\mathrm{C}$ (Duration) & 1.88 & 0.1918 & $0.004049 \times(C \times D)-0.271126 \times A^{2}+0.000056 \times B^{2}-$ \\
\hline $\mathrm{D}(\mathrm{pH})$ & 8.53 & 0.0112 & $0.000547 \times \mathrm{C}^{2}+0.018996 \times \mathrm{D}^{2}$ \\
\hline $\mathrm{AB}$ & 1.50 & 0.2403 & \\
\hline $\mathrm{AC}$ & 7.01 & 0.0191 & $\mathrm{R}^{2}: 0.771$ \\
\hline $\mathrm{AD}$ & 0.25 & 0.6241 & Adeq Precision: 7.716 \\
\hline $\mathrm{BC}$ & 6.07 & 0.0273 & \\
\hline $\mathrm{BD}$ & 3.11 & 0.0995 & \\
\hline $\mathrm{CD}$ & 2.30 & 0.1515 & \\
\hline $\mathrm{A}^{2}$ & 8.57 & 0.0110 & \\
\hline $\mathrm{B}^{2}$ & 0.02 & 0.8829 & \\
\hline $\mathrm{C}^{2}$ & 2.09 & 0.1699 & \\
\hline $\mathrm{D}^{2}$ & 2.63 & 0.1275 & \\
\hline Source & \multicolumn{2}{|c|}{$\left(\mathrm{O}_{3}+\mathrm{H}_{2} \mathrm{O}_{2}\right)$ process } & Model Equation \\
\hline & F value & $P$ value & $q_{e}(\mathrm{mg}$ dye $/ \mathrm{g} \mathrm{GAC})=+4.85109+3.32859 \times \mathrm{A}-$ \\
\hline Model & 4.57 & 0.0038 & $0.042681 \times \mathrm{B}-0.046500 \times+0.026122 \times \mathrm{D}+0.001722 \times$ \\
\hline $\mathrm{A}\left(\mathrm{H}_{2} \mathrm{O}_{2}\right)$ & 0.36 & 0.5573 & $(A \times B)-0.041780 \times(A \times C)-0.062959 \times(A \times D)+$ \\
\hline $\mathrm{B}$ (Ozone) & 0.46 & 0.5082 & $0.000025 \times(B \times C)+0.003511 \times(B \times D)+0.003619 \times$ \\
\hline $\mathrm{C}$ (Duration) & 8.36 & 0.0118 & $(C \times D)+0.016790 \times A^{2}+0.000110 \times B^{2}+0.000556 \times$ \\
\hline $\mathrm{D}(\mathrm{pH})$ & 2.14 & 0.1658 & $\mathrm{C}^{2}-0.028205 \times \mathrm{D}^{2}$ \\
\hline $\mathrm{AB}$ & 0.02 & 0.8663 & \\
\hline $\mathrm{AC}$ & 21.91 & 0.0004 & $\mathrm{R}^{2}: 0.820$ \\
\hline $\mathrm{AD}$ & 0.61 & 0.4463 & Adeq Precision: 9.222 \\
\hline $\mathrm{BC}$ & 0.01 & 0.9111 & \\
\hline $\mathrm{BD}$ & 3.18 & 0.0961 & \\
\hline $\mathrm{CD}$ & 4.28 & 0.0576 & \\
\hline $\mathrm{A}^{2}$ & 0.002 & 0.9591 & \\
\hline $\mathrm{B}^{2}$ & 0.32 & 0.5779 & \\
\hline $\mathrm{C}^{2}$ & 13.25 & 0.0027 & \\
\hline $\mathrm{D}^{2}$ & 5.20 & 0.0387 & \\
\hline
\end{tabular}

392

\subsection{Preference of The Most Suitable Regeneration Process with PROMETHEE}

PROMETHEE, one of the multi-criteria decision-making methods, was used for the preference of the three regeneration processes examined in this study. In the preference of the most suitable regeneration process, the adsorptive capacity of the regenerated GAC, the operating cost of the regeneration process, the change in the adsorptive capacity during the regeneration cycle and the carbon mass loss were taken 
into consideration as criteria. Optimum conditions of regeneration processes were used for the adsorptive capacity of the regenerated GAC and the operating cost of the regeneration process criteria. The $6^{\text {th }}$ cycle of the regeneration cycle was considered for the adsorptive capacity change and carbon mass loss criteria. Energy (MW oven, ozone generator) and chemical matter consumption $\left(\mathrm{PS}, \mathrm{H}_{2} \mathrm{SO}_{4}\right.$, $\mathrm{NaOH}, \mathrm{FeSO}_{4}, \mathrm{H}_{2} \mathrm{O}_{2}$ ) were used when calculating the operating cost for optimum conditions. The unit energy cost was accepted as $0.094 € / \mathrm{kWh}$ according to the energy consumption cost for the home / residential of TEDAŞ (Turkey Electricity Distribution Company).

GAC regeneration aims to restore the original adsorption capacity of GAC with the least possible damage to the carbon surface. Therefore, it is important that the regenerated GAC can be used for several regeneration cycles. In this study, the change in the adsorptive capacity of regenerated GAC was observed with sequential regeneration-adsorption cycles. Fig. 5 shows the change in the adsorptive capacity with the regeneration cycles of (MW + PS), (Fe (II) + PS) and $\left(\mathrm{O}_{3}+\mathrm{H}_{2} \mathrm{O}_{2}\right)$ processes. For SRS3B dye, the adsorptive capacity of raw activated carbon and the adsorptive capacity of spent GAC were found to be $8.01 \mathrm{mg}$ dye / g GAC and $2.18 \mathrm{mg}$ dye / g GAC, respectively.

The efficiency of regeneration processes was evaluated by comparing the adsorptive capacities of regenerated and raw GAC. The adsorptive capacity of GAC regenerated by the (Fe (II) + PS) process $(\approx 9.4 \mathrm{mg} / \mathrm{g}$ GAC) was obtained above the adsorptive capacity of raw GAC (8.01 mg / g GAC) during eight regeneration cycles. With the $\left(\mathrm{O}_{3}+\mathrm{H}_{2} \mathrm{O}_{2}\right)$ process, only the first regeneration cycle yielded higher adsorptive capacity than the raw GAC, and the decrease was observed with the regeneration cycle increase. In regeneration with (MW + PS) process, the adsorptive capacity of raw GAC could not be reached.

The carbon mass loss calculated in the 6th regeneration cycle was calculated as $26 \%, 31.2 \%$ and $37 \%$ for (MW + PS), $(\mathrm{Fe}(\mathrm{II})+\mathrm{PS})$ and $\left(\mathrm{O}_{3}+\mathrm{H}_{2} \mathrm{O}_{2}\right)$ processes, respectively. Table 4 shows the criterion values calculated for all three processes for PROMETHEE analysis.

$>$ Fig. 5 Adsorptive capacities corresponding to sequential regeneration cycles of regeneration processes< 


\begin{tabular}{ccccc}
\hline Process & $\begin{array}{c}\text { Adsorptive capacity } \\
\mathrm{q}_{\mathrm{e}}(\mathrm{mg} \text { dye/g GAC) }\end{array}$ & $\begin{array}{c}\text { Operation cost } \\
(€)\end{array}$ & $\begin{array}{c}\text { Adsorptive Capacity } \\
\text { Change }(\%)\end{array}$ & $\begin{array}{c}\text { Carbon } \\
\text { mass loss } \\
(\%)\end{array}$ \\
\hline $\mathrm{MW}+\mathrm{PS}$ & 4.36 & 0.177 & 60.30 (reduce) & 26 \\
$\mathrm{Fe}(\mathrm{II})+\mathrm{PS}$ & 8.89 & 0.306 & 17.23 (increase) & 31.2 \\
$\mathrm{O}_{3}+\mathrm{H}_{2} \mathrm{O}_{2}$ & 8.12 & 0.281 & 36.08 (reduce) & 37 \\
\hline
\end{tabular}

424 While choosing the most suitable method with PROMETHEE, weights of all criteria were taken equal 425 and V-shape was used among preference functions. PROMETHEE I is used for partial ranking and 426 PROMETHEE II for net ranking. Positive and negative currents are calculated for alternatives. Positive 427 current indicates preferability of one alternative over others, while negative current, on the contrary, indicates how much an alternative is suppressed by others. Therefore, high positive current and small negative current of an alternative increases its preferability. PROMETHEE II gives a net ranking as it expresses the difference between positive and negative currents. The GAIA plane is a visual and interactive representation of the PROMETHEE results. In the GAIA plane, the decision axis is indicated by a red vector and is near the most preferred alternative. Also, alternatives near the criteria indicate the particular preferred alternative for that criterion (Durna et al. 2020). PROMETHEE II net ranking and GAIA plane given in Fig. 6. As shown in Figure, the Fe (II) + PS process is more preferred in positive and negative currents and consequently in net current. PROMETHEE II ranking of regeneration processes was determined as $(\mathrm{Fe}(\mathrm{II})+\mathrm{PS})>(\mathrm{MW}+\mathrm{PS})>\left(\mathrm{O}_{3}+\mathrm{H}_{2} \mathrm{O}_{2}\right)$. In the GAIA plane, the decision axis was on the Fe (II) + PS process side. The MW + PS process is preferable when evaluated by the carbon mass loss criteria. With PROMETHEE Rainbow analysis (Supplementary information Fig S4) the positive and negative factors affecting the sequencing of the processes can be clearly seen in the form of bars. Positive (upward) slices correspond to good properties, negative (downward) slices to negative properties. ${ }^{40}$ While adsorptive capacity, adsorptive capacity change and carbon mass loss criteria positively affected the selection of $\mathrm{Fe}$ (II) + PS process, operation cost criterion affected negatively.

$>$ Fig. 6 PROMETHEE II net ranking (a) and GAIA plane (b) of regeneration processes<

\section{Conclusion}

This study was carried out in three stages. In the first stage, the adsorption of the SR-S3B on the GAC surface was characterized. In the second stage, regeneration of SR-S3B spent GAC by radical-based advanced oxidation processes was investigated. $\left(\mathrm{O}_{3}+\mathrm{H}_{2} \mathrm{O}_{2}\right)$ for $\mathrm{OH}^{\bullet}$ radical, $(\mathrm{MW}+\mathrm{PS})$ and $(\mathrm{Fe}(\mathrm{II})+$ PS) regeneration processes for $\mathrm{SO}^{-}{ }^{-}$radical were investigated. At the last stage, the most suitable 
adsorptive capacity of regenerated GAC, operating cost of the regeneration process, change in the adsorptive capacity during the regeneration cycle, and carbon mass loss. The results obtained are given below.

- Chemical interactions are effective in the adsorption of the SR-S3B to the GAC surface. The adsorption process has been characterized by the Langmuir isotherm.

- Regeneration processes were optimized by the RSM method to determine the experimental conditions that will give the maximum adsorptive capacity. Optimum experimental conditions for the (MW + PS) process were found as MW power of $126 \mathrm{~W}$, PS of $45.52 \mathrm{~g}$ anion/L, $\mathrm{pH}$ of 11.4, , duration of $14.56 \mathrm{~min}$. Optimum conditions for (Fe (II) + PS) process were found as Fe (II) $3.58 \mathrm{~g} / \mathrm{L}$, PS $73.5 \mathrm{~g}$ anion / L, time 59.8 minutes, $\mathrm{pH} 10.9$ and for the $\left(\mathrm{O}_{3}+\mathrm{H}_{2} \mathrm{O}_{2}\right)$ process optimum conditions found as $\mathrm{H}_{2} \mathrm{O}_{2}$ of 2.8 mole/L, ozone doze of $\% 98$, duration of $32.8, \mathrm{pH}$ of 5.3. Adsorptive capacities at optimum conditions were obtained as 4.36, 8.89 and 8.12 for $(\mathrm{MW}+\mathrm{PS}),(\mathrm{Fe}(\mathrm{II})+\mathrm{PS})$ and $\left(\mathrm{O}_{3}+\mathrm{H}_{2} \mathrm{O}_{2}\right)$ processes, respectively. The adsorptive capacity of GAC regenerated by the (Fe (II) + PS) regeneration process was obtained above the raw GAC adsorptive capacity during approximately eight regeneration cycles.

-A linear relationship was observed between the experimentally obtained data and the data predicted by the model.

- ANOVA results revealed that binary interactions are more important in improving the adsorptive capacity in regeneration processes. The major operating parameter in these binary interactions has been the regeneration time. In addition, it was determined that the parameters of $\mathrm{pH}$ and regeneration time alone were effective in ( $\mathrm{Fe}(\mathrm{II})+\mathrm{PS})$ and $\left(\mathrm{O}_{3}+\mathrm{H}_{2} \mathrm{O}_{2}\right)$ processes, respectively, in order to improve the adsorptive capacity.

- The most suitable regeneration process has been determined with the PROMETHEE approach. The order of preference is determined as $(\mathrm{Fe}(\mathrm{II})+\mathrm{PS})>(\mathrm{MW}+\mathrm{PS})>\left(\mathrm{O}_{3}+\mathrm{H}_{2} \mathrm{O}_{2}\right)$. In this ranking, the adsorption capacity change criterion was very effective in determining the most suitable process. As a result, it has been seen that the (Fe (II) + PS) process is a promising alternative for regeneration of GAC spent with reactive dye.

\section{Declarations}

Ethical approval Not applicable.

\section{Consent to participate Not applicable.}

Consent for publication Not applicable. 
483 Competing interests The authors declare no competing interests.

484 Funding No funding was received to assist with the preparation of this manuscript.

485

486

487

488

489

490

491

492

493

494

495

496

497

498

499

500

501

502

503

504

505

506

507

508

509

510

511

512

513

514

\section{Author Contributions}

Study conceptualization, investigation, manuscript reviewing, and editing were performed by Nevim GENÇ and Elif DURNA, experimental analysis was performed by Esin KACIRA.

\section{References}

Alvárez PM, Beltrán FJ, Masa FJ, Pocostales JP (2009) A comparison between catalytic ozonation and activated carbon adsorption/ozone-regeneration processes for wastewater treatment. Appl Catal B 92(3-4):393-400. https://doi.org/10.1016/j.apcatb.2009.08.019

Alvárez PM, Beltrán FJ, Gómez-Serrano V, Jaramillo J, Rodríguez EM (2004) Comparison between thermal and ozone regenerations of spent activated carbon exhausted with phenol. Water Res 38(8):2155-2165. https://doi.org/10.1016/j.watres.2004.01.030

An D, Westerhoff P, Zheng M, Wu M, Yang Y, Chiu CA (2015) UV-activated persulfate oxidation and regeneration of NOM-Saturated granular activated carbon. Water Res 73:304-310. https://doi.org/10.1016/j.watres.2015.01.040

Ania CO, Parra JB, Menéndez JA, Pis JJ (2005) Effect of microwave and conventional regeneration on the microporous and mesoporous network and on the adsorptive capacity of activated carbons. Microporous Mesoporous Mater 85(1-2):7-15. https://doi.org/10.1016/j.micromeso.2005.06.013

Bakht Shokouhi S, Dehghanzadeh R, Aslani H, Shahmahdi N (2020) Activated carbon catalyzed ozonation (ACCO) of Reactive Blue 194 azo dye in aqueous saline solution: Experimental parameters, kinetic and analysis of activated carbon properties. J Water Process Eng 35:101188. https://doi.org/10.1016/j.jwpe.2020.101188

Bapat S, Jaspal D, Malviya A (2021) Efficacy of parthenium hysterophorus waste biomass compared with activated charcoal for the removal of CI Reactive Red 239 textile dye from wastewater. Color Technol. cote.12526. https://doi.org/10.1111/cote.12526

Barabadi H, Honary S, Ebrahimi P, Alizadeh A, Naghibi F, Saravanan M (2019) Optimization of mycosynthesized silver nanoparticles by response surface methodology employing Box-Behnken design. Inorg Nano-Metal Chem 49(2):33-43. https://doi.org/10.1080/24701556.2019.1583251

Beulah SS, Muthukumaran K (2020) Methodologies of Removal of Dyes from Wastewater: A Review. Int Res J Pure Appl Chem IRJPAC(11):68-78. https://doi.org/10.9734/irjpac/2020/v21i1130225

Brans JP, Vincke P, Mareschal B (1986) How to select and how to rank projects: The Promethee method. Eur J Oper Res 24(2):228-238. https://doi.org/10.1016/0377-2217(86)90044-5

Cabrera-Codony A, Gonzalez-Olmos R, Martín MJ (2015) Regeneration of siloxane-exhausted activated carbon by advanced oxidation processes. J Hazard Mater 285:501-508. https://doi.org/10.1016/j.jhazmat.2014.11.053

Charnkeitkong P, Phoophuangpairoj R (2020) Modification of Manila Grass Activated Carbon for Reactive Dye Adsorption from Textile Printing Wastewater. IOP Conf Ser Mater Sci Eng 733(1):012043. https://doi.org/10.1088/1757-899X/733/1/012043

Durán-Jiménez G, Stevens LA, Hodgins GR, Uguna J, Ryan J, Binner ER, Robinson JP (2019) Fast regeneration of activated carbons saturated with textile dyes: Textural, thermal and dielectric characterization. Chem Eng J 378:121774. https://doi.org/10.1016/j.cej.2019.05.135

Durna E, Erkişi E, Genç N (2020) Regeneration of diclofenac-spent granular activated carbon by sulphate radical based methods: multi-response optimisation of adsorptive capacity and operating cost. Int J Environ Anal Chem 1-15. https://doi.org/10.1080/03067319.2020.1787399

Durna E, Koz G, Genç N (2020) Determination of the Most Suitable Disposal Option in the Management of End 
of Life Tires in Turkey by PROMETHEE and Fuzzy PROMETHEE Method. Journal of Polytechnic 23:915-927. 10.2339/politeknik.591100

Genç N, Durna E, Erkişi E (2021) Optimization of the adsorption of diclofenac by activated carbon and the acidic regeneration of spent activated carbon. Water Sci Technol 83(2):396-408. https://doi.org/10.2166/wst.2020.577

He X, Elkouz M, Inyang M, Dickenson E, Wert EC (2017) Ozone regeneration of granular activated carbon for trihalomethane control. J Hazard Mater 326:101-109. https://doi.org/10.1016/j.jhazmat.2016.12.016

Huling SG, Ko S, Park S, Kan E (2011) Persulfate oxidation of MTBE- and chloroform-spent granular activated carbon. J Hazard Mater 192(3):1484-1490. https://doi.org/10.1016/j.jhazmat.2011.06.070

Hutson A, Ko S, Huling SG (2012) Persulfate oxidation regeneration of granular activated carbon: Reversible $\begin{array}{llll}\text { impacts on } & \text { borption } & \text { Chemosphere } & \text { 89):1218-1223. }\end{array}$ https://doi.org/10.1016/j.chemosphere.2012.07.040

Jatta S, Huang S, Liang C (2019) A column study of persulfate chemical oxidative regeneration of toluene gas saturated activated carbon. Chem Eng J 375:122034. https://doi.org/10.1016/j.cej.2019.122034

Larasati A, Fowler GD, Graham NJD (2020) Chemical regeneration of granular activated carbon: Preliminary evaluation of alternative regenerant solutions. Environ Sci Water Res Technol 6(8):2043-2056. https://doi.org/10.1039/d0ew00328j

Leng CC, Pinto NG (1996) An investigation of the mechanisms of chemical regeneration of activated carbon. Ind Eng Chem Res 35(6):2024-2031. https://doi.org/10.1021/ie950576a

Liang C, Lin YT, Shin WH (2009) Persulfate regeneration of trichloroethylene spent activated carbon. J Hazard Mater 168(1):187-192. https://doi.org/10.1016/j.jhazmat.2009.02.006

Liu Z, Ren B, Ding H, He H, Deng H, Zhao C, Wang P, Dionysiou DD (2020) Simultaneous regeneration of cathodic activated carbon fiber and mineralization of desorbed contaminations by electro-peroxydisulfate process: Advantages and limitations. Water Res 171:115456. https://doi.org/10.1016/j.watres.2019.115456

Lu PJ, Lin HC, Yu WT, Chern JM (2011) Chemical regeneration of activated carbon used for dye adsorption. J Taiwan Inst Chem Eng 42(2):305-311. https://doi.org/10.1016/j.jtice.2010.06.001

McQuillan RV, Stevens GW, Mumford KA (2018) The electrochemical regeneration of granular activated carbons: A review. J Hazard Mater 55:34-49. https://doi.org/10.1016/j.jhazmat.2018.04.079

Moradi O, Fakhri A, Adami S, Adami S (2013) Isotherm, thermodynamic, kinetics, and adsorption mechanism studies of Ethidium bromide by single-walled carbon nanotube and carboxylate group functionalized single-walled carbon nanotube. J Colloid Interface Sci 395(1):224-229. https://doi.org/10.1016/j.jcis.2012.11.013

Moyo LB, Iyuke SE, Muvhiiwa RF, Simate GS, Hlabangana N (2021) Application of response surface methodology for optimization of biodiesel production parameters from waste cooking oil using a membrane reactor. South African J Chem Eng 35:1-7. https://doi.org/10.1016/j.sajce.2020.10.002

Oladejo J, Shi K, Chen Y, Luo X, Gang Y, Wu T (2020) Closing the active carbon cycle: Regeneration of spent activated carbon from a wastewater treatment facility for resource optimization. Chem Eng Process Process Intensif 150:107878. https://doi.org/10.1016/j.cep.2020.107878

Patel S, Majumder SK, Das P, Ghosh P (2019) Ozone microbubble-aided intensification of degradation of naproxen in a plant prototype. J Environ Chem Eng 7(3), 103102. https://doi.org/10.1016/j.jece.2019.103102

Rais S, Islam A, Ahmad I, Kumar S, Chauhan A, Javed H (2021) Preparation of a new magnetic ion-imprinted polymer and optimization using Box-Behnken design for selective removal and determination of $\mathrm{Cu}$ (II) in food and wastewater samples. Food Chem 334:127563. https://doi.org/10.1016/j.foodchem.2020.127563

Sahu UK, Mahapatra SS, Patel RK (2018) Application of Box-Behnken Design in response surface methodology for adsorptive removal of arsenic from aqueous solution using $\mathrm{CeO} 2 / \mathrm{Fe} 2 \mathrm{O} 3 /$ graphene nanocomposite. Mater Chem Phys 207:233-242. https://doi.org/10.1016/j.matchemphys.2017.11.042

Salvador F, Martin-Sanchez N, Sanchez-Hernandez R, Sanchez-Montero MJ, Izquierdo C (2015a) Regeneration 
of carbonaceous adsorbents. Part I: Thermal Regeneration. Microporous Mesoporous Mater 202:259-276. https://doi.org/10.1016/j.micromeso.2014.02.045

Salvador F, Martin-Sanchez N, Sanchez-Hernandez R, Sanchez-Montero MJ, Izquierdo C (2015b) Regeneration of carbonaceous adsorbents. Part II: Chemical, Microbiological and Vacuum Regeneration. Microporous Mesoporous Mater 202:277-296). https://doi.org/10.1016/j.micromeso.2014.08.019

Santos DHS, Duarte JLS, Tonholo J, Meili L, Zanta CLPS (2020) Saturated activated carbon regeneration by UV-light, H2O2 and Fenton reaction. Sep Purif Technol 250:117112. https://doi.org/10.1016/j.seppur.2020.117112

Senthil Kumar P (2014) Adsorption of lead(II) ions from simulated wastewater using natural waste: A kinetic, thermodynamic and equilibrium study. Environ Prog Sustain Energy 33(1):55-64. https://doi.org/10.1002/ep.11750

Singh R, Bhunia P, Dash RR (2019) Optimization of organics removal and understanding the impact of HRT on vermifiltration of brewery wastewater. Sci Total Environ 651:1283-1293. https://doi.org/10.1016/j.scitotenv.2018.09.307

Srikanth HV, Venkatesh J, Godiganur S (2021) Box-Behnken Response Surface Methodology for Optimization of Process Parameters for Dairy Washed Milk Scum Biodiesel Production. Biofuels 12(1):113-123. https://doi.org/10.1080/17597269.2018.1461511

Vakili M, Zwain HM, Mojiri A, Wang W, Gholami F, Gholami Z, Giwa AS, Wang B, Cagnetta G, Salamatinia B (2020) Effective Adsorption of Reactive Black 5 onto Hybrid Hexadecylamine Impregnated ChitosanPowdered Activated Carbon Beads. Water 12(8):2242. https://doi.org/10.3390/w12082242

Zanella O, Tessaro IC, Féris LA (2014) Desorption- and Decomposition-Based Techniques for the Regeneration of Activated Carbon. Chem Eng Technol 37(9):1447-1459. https://doi.org/10.1002/ceat.201300808

Zhang CL, Qiao GL, Zhao F, Wang Y (2011) Thermodynamic and kinetic parameters of ciprofloxacin adsorption onto modified coal fly ash from aqueous solution. J Mol Liq 163(1):53-56. https://doi.org/10.1016/j.molliq.2011.07.005 
Figures

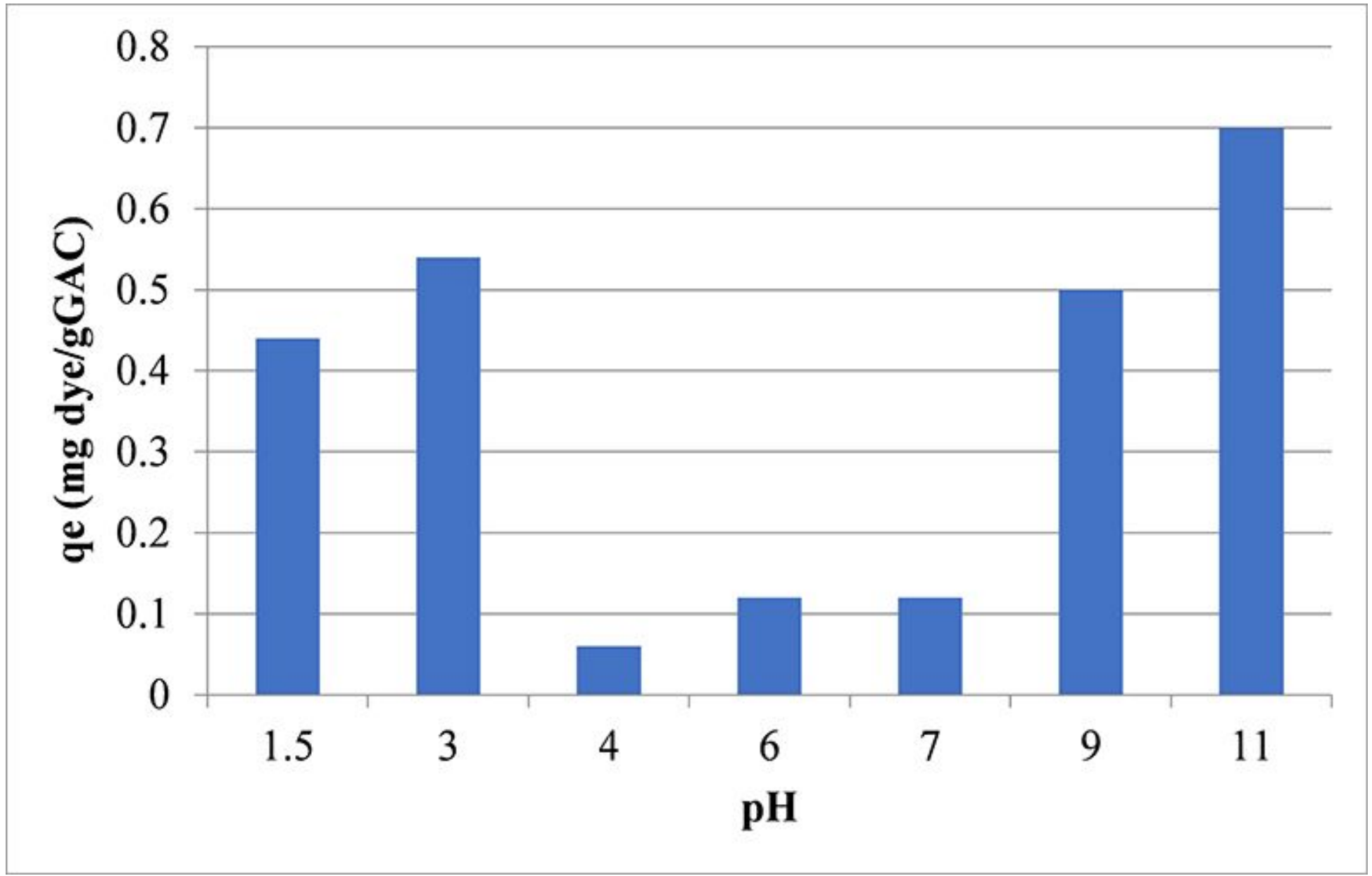

Figure 1

Change of the adsorptive capacity versus $\mathrm{pH}$ of reactive dye (SR-S3B) solution 

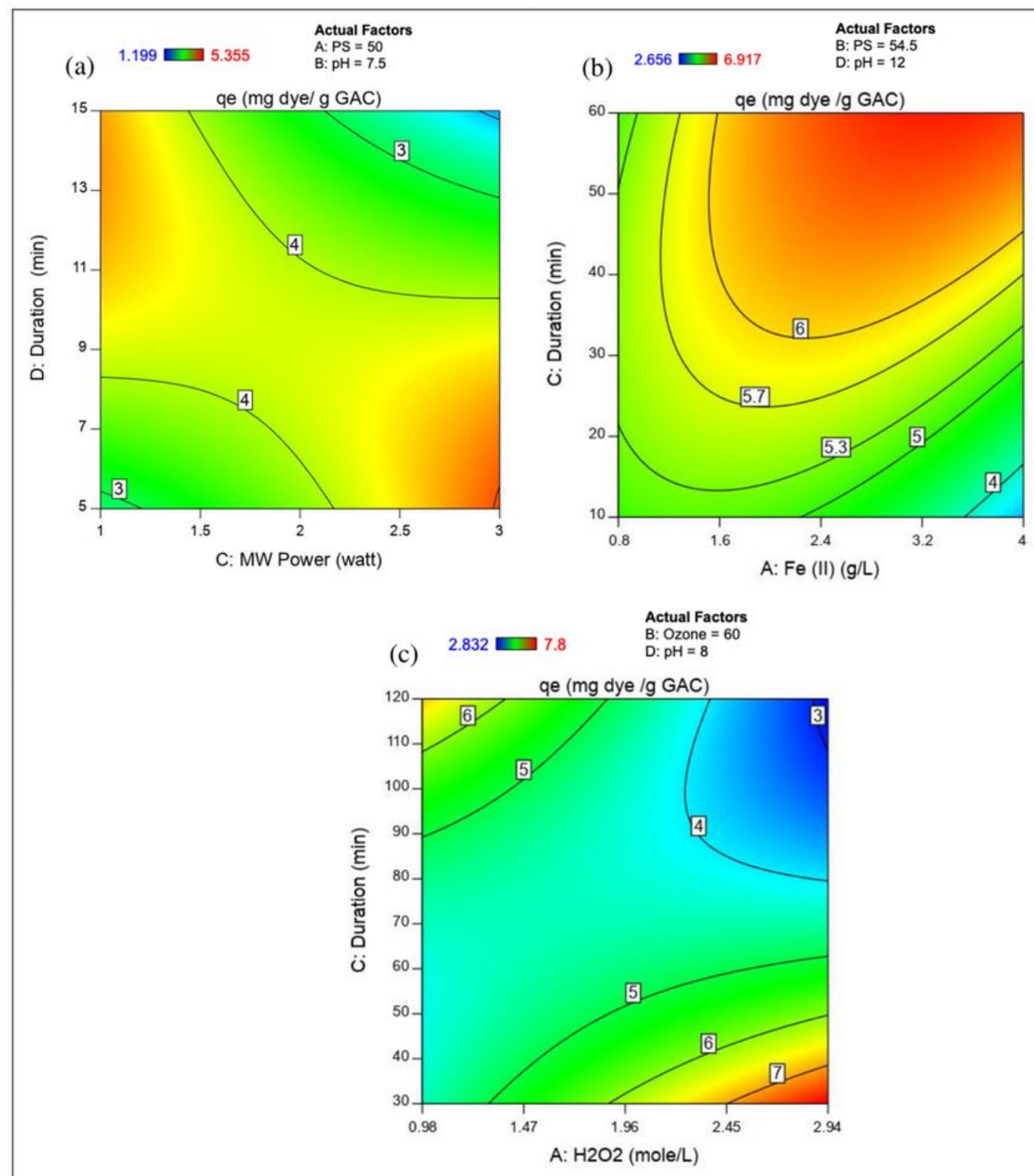

Figure 2

Contour graphs of binary interactions of important parameters in regeneration processes (a), (b) and (c) corresponds (MW + PS), ( $\mathrm{Fe}(\mathrm{II})+\mathrm{PS})$ and $(\mathrm{O} 3+\mathrm{H} 2 \mathrm{O} 2)$ processes, respectively 


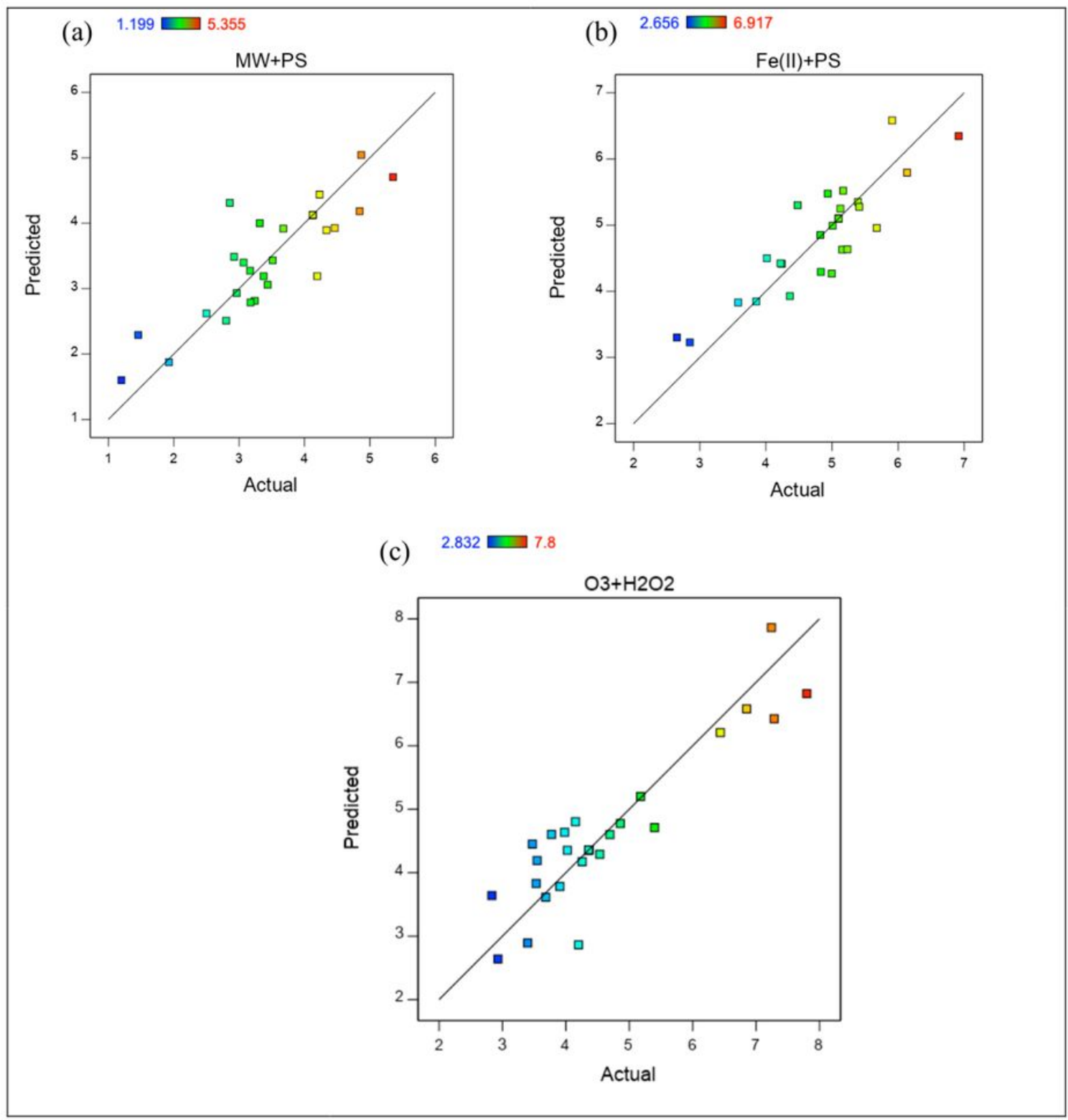

Figure 3

Predicted versus actual plots of regeneration processes (a), (b) and (c) corresponds (MW + PS), (Fe (II) + $\mathrm{PS})$ and $(\mathrm{O} 3+\mathrm{H} 2 \mathrm{O} 2)$ processes, respectively 
MW + PS Process (PS anion of $45.52 \mathrm{~g} / \mathrm{L}, \mathrm{pH}$ of 11.4, MW power of 126 watt, duration of $14.56 \mathrm{~min}$ )

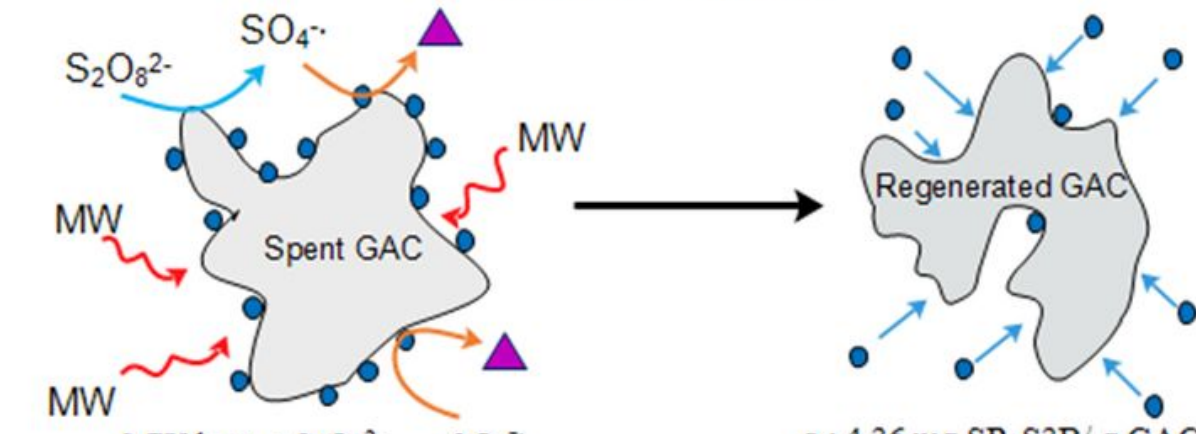

MW heat $+\mathrm{S}_{2} \mathrm{O}_{8}{ }^{2-} \rightarrow \mathrm{SO}_{4}{ }^{-}$

qe: $4.36 \mathrm{mg} \mathrm{SR}-\mathrm{S} 3 \mathrm{~B} / \mathrm{g}$ GAC

$\mathrm{Fe}(\mathrm{II})+$ PS Process (Fe (II) of $3.58 \mathrm{~g} / \mathrm{L}$, PS anion of $73.5 \mathrm{~g} /$, duration of 59.9 $\mathrm{min}, \mathrm{pH}$ of 10.9)
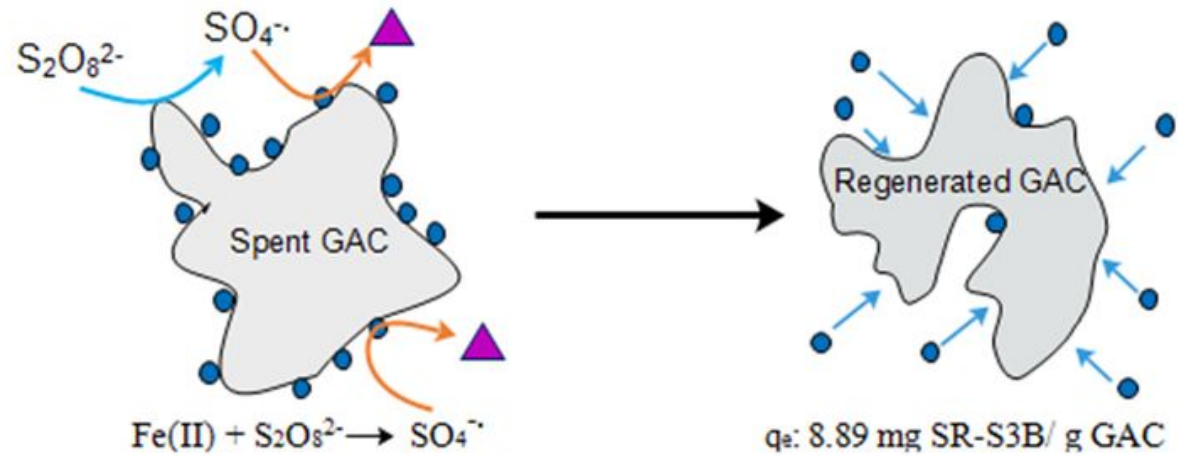

qe: $8.89 \mathrm{mg} \mathrm{SR}-\mathrm{S} 3 \mathrm{~B} / \mathrm{g} \mathrm{GAC}$

$\mathrm{O}_{3}+\mathrm{H}_{2} \mathrm{O}_{2}$ Process $\left(\mathrm{H}_{2} \mathrm{O}_{2}\right.$ of $2.8 \mathrm{~mole} / \mathrm{L}$, ozone doze of $\% 98$, duration of 32.8

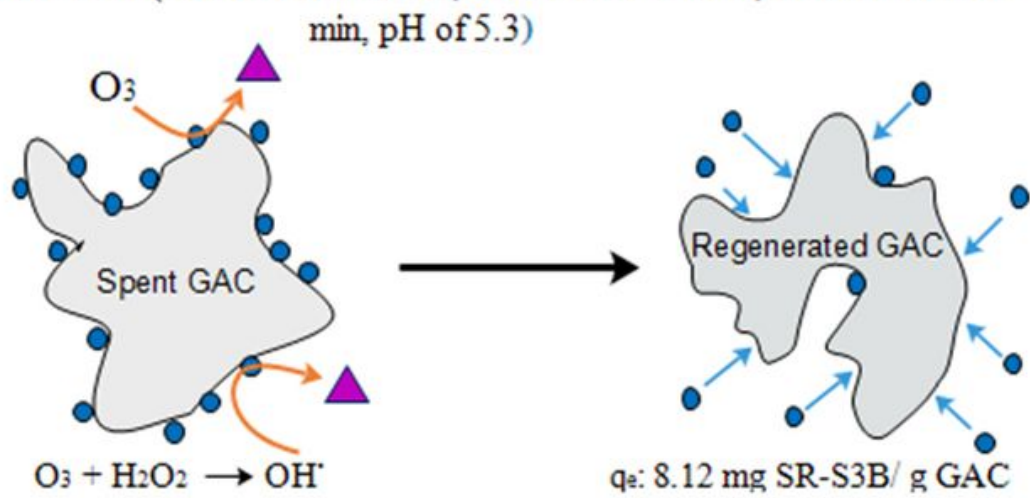

$\triangle=$ SR-S3B (reactive dye)
$\Delta=$ intermediate / ultimate product

Figure 4

Optimum conditions and possible oxidation mechanisms of regeneration processes 


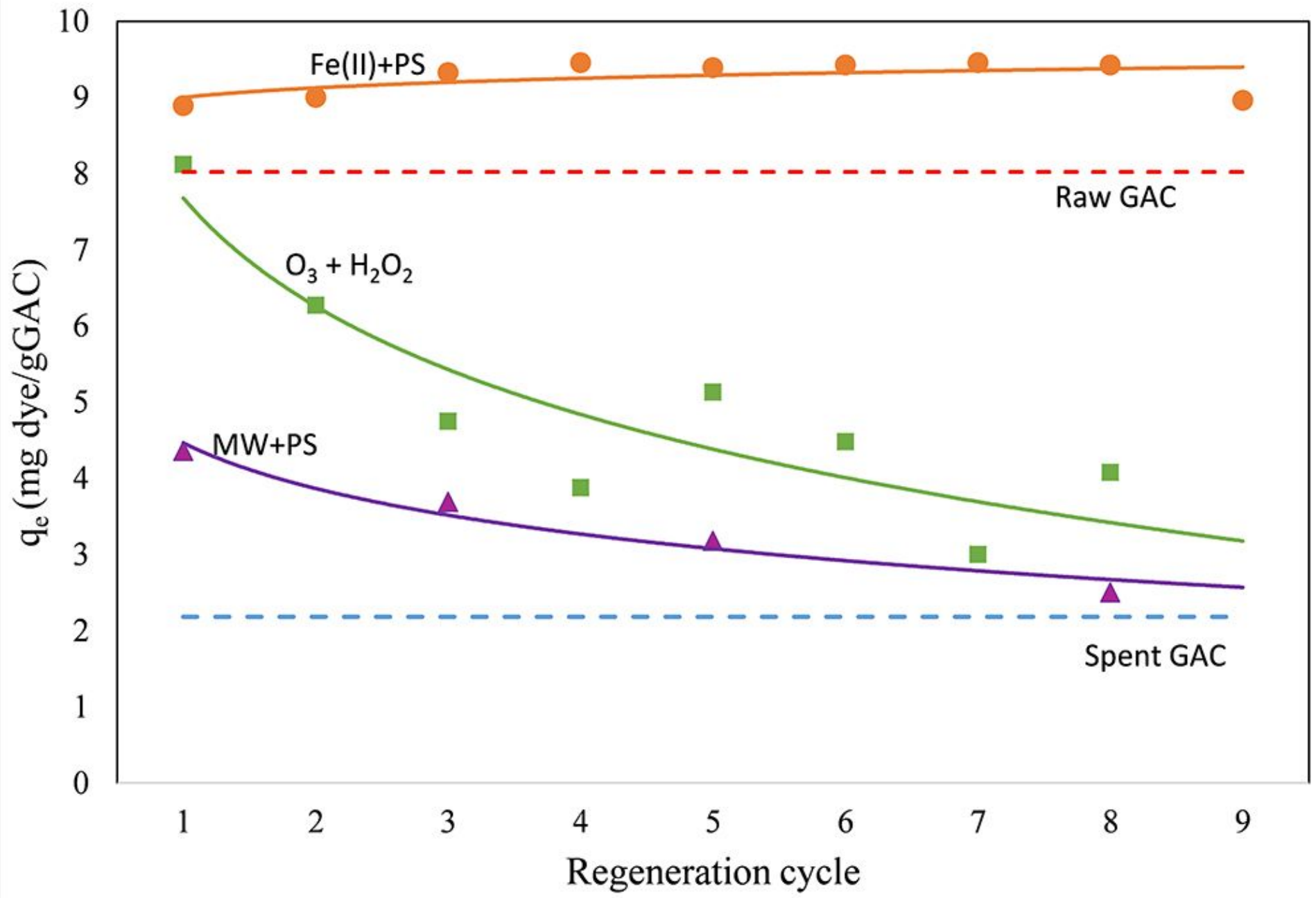

Figure 5

Adsorptive capacities corresponding to sequential regeneration cycles of regeneration processes 


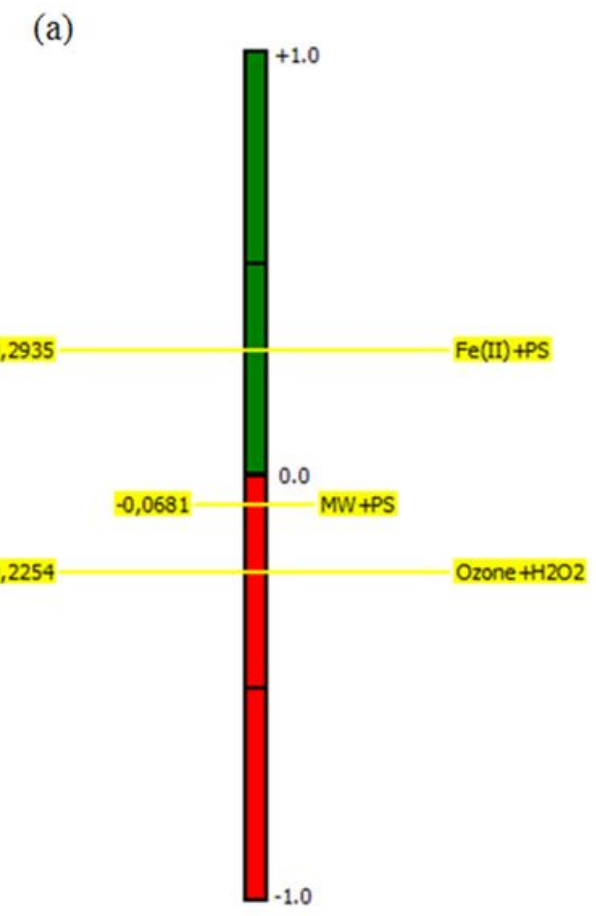

(b)

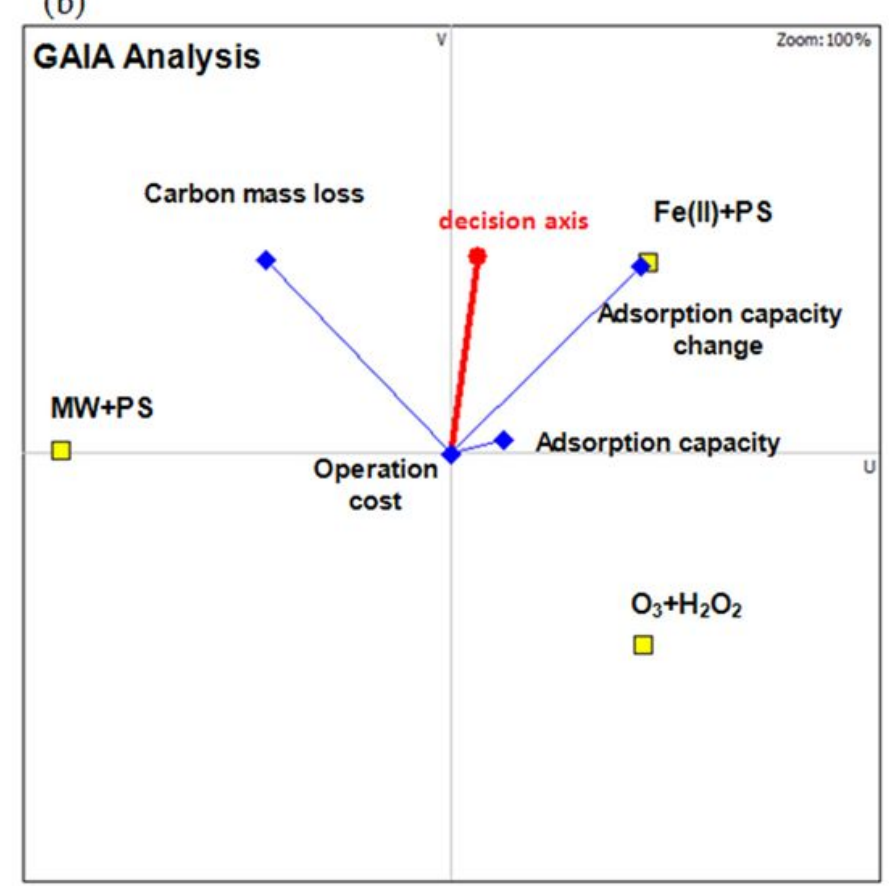

Figure 6

PROMETHEE II net ranking (a) and GAIA plane (b) of regeneration processes

\section{Supplementary Files}

This is a list of supplementary files associated with this preprint. Click to download.

- renamed3f1f3.docx 